\title{
Mixed Methods Study to Explore the Portrait of Micro and Small Enterprises in Semarang City During the Covid-19 Pandemic
}

\author{
$1^{\text {st }}$ Gregorius Nasiansenus \\ Masdjojo \\ Economic and Business Faculty \\ Stikubank University \\ Semarang, Indonesia \\ masdjojo@edu.unisbank.ac.id
}

\author{
$2^{\text {nd }}$ Titiek Suwarti \\ Economic and Business Faculty \\ Stikubank University \\ Semarang, Indonesia \\ titiek_suwarti@edu.unisbank.ac.id
}

\author{
$3^{\text {rd }}$ Ida Nurhayati \\ Economic and Business Faculty \\ Stikubank University \\ Semarang, Indonesia \\ ida.nurhayati@edu.unisbank.ac.id
}

\author{
$4^{\text {th }}$ Listiyorini Wahyu Widarti \\ Economic and Business Faculty \\ Stikubank University \\ Semarang, Indonesia \\ listiyorini@edu.unisbank.ac.id
}

\begin{abstract}
This study aims to explore the portrait of SMEs during and after the Covid-19 pandemic. The respondents are more than 500 SME actors in Semarang City. Data are collected and analysed by a mixed method.

The results show that the SMEs have very various types of business. The length of running business also varies. Many millennials are involved in this sector. The initial capital they use is very varied. The income they receive is also very volatile. Before the Covid-19 pandemic, they generally admit that their income tends to increase relatively. However, during the Covid-19 pandemic, most of them experienced a sharp decline in results. The contributing factor that they conveyed was the existence of a government policy. This research finds that some catering businesses experienced an increased income. A type of business that uses social media assistance has also increased rapidly during the Covid-19 pandemic. This research also finds that most of the SME actors don't receive crisis assistance through various programs. The reason is that they lack access to information. Some of these results confirm the findings of previous studies. However, most of the findings are recognized as initial embryos to be investigated further in future research.
\end{abstract}

Keywords: Micro and Medium Enterprises, Pandemic Covid-19, Crisis Gripping Strategies, Exploration Studies

\section{INTRODUCTION}

Small and Medium Enterprises (SMEs) have played a role in supporting Indonesia's economy. The Ministry of Cooperatives and SMEs records that the number of SMEs in Indonesia reach 65 million business actors. That is $99.9 \%$ of all businesses in Indonesia.

During the Covid-19 pandemic, the SME sector is most affected. There are even some SME entrepreneurs who close their businesses. Then the Secretary of the Ministry of Cooperatives and SMEs say that there are variations in the impact experienced by SME entrepreneurs during the Covid19 pandemic. There are $30 \%$ who experience a business interruption. However, what is interesting is that $50-70 \%$ of them experience severe disruption, but they can create creative innovations to escape the crisis.

Furthermore, the Secretary of the Ministry of Cooperatives and SMEs also say that some SMEs still exist and grow. That is known as an impact of assistance programs from the government in the National Economic Recovery (NER) scheme such as relaxation of credit, interest subsidies, working capital, and Productive Presidential Assistance for micro-businesses in the form of grants. Observations of the Ministry of Cooperatives and SMEs show that SMEs' sales in e-commerce rise by 26 percent or reach 3.1 million transactions per day during the pandemic period. Some SME players have taken advantage of technological development facilities such as business digitization.

This study aims to explore the conditions of SMEs before and after the Covid-19 pandemic. The goal is to know how their attitude is in dealing with the Covid-19 pandemic. The city of Semarang become the object of the research area.

This study involved 70 students as enumerators. Thus, the target respondents interviewed are about 700 SME actors. The data collection method uses direct and indirect interview techniques. The duration of time required for data collection to tabulation is one month, namely during October 2020.

From the primary data collected, it is processed simply by the frequency distribution method. Then graphs are used to display the results of the research. Based on the distribution in these graphs, the researchers then created a narrative to describe the characteristics, attitudes, and business strategies of micro and small business actors in Semarang City in a covid19 pandemic.

\section{PREVIOUS RESEARCH}

During 2020 many types of research are conducted to explore the impact of the Covid-19 pandemic on the economic 
sector. The focus of these studies is quite diverse in their analysis methods. Not many researchers have found the effect of the Covid-19 pandemic on SMEs. The following paragraphs will describe several studies that support this research.

According to a study in Malaysia, SMEs contribute to Malaysia's GDP, employment opportunities, and export activities. However, there has been no attention to this sector, especially when it is facing a disaster. The ability to mitigate risks due to disasters is still weak. [1]

A study in China found that the COVID-19 outbreak impact sectors with unskilled labour than sectors with skilled labour. When the economy began to recover after the Covid-19 disaster, the food agriculture sector grows positively. Thus, many job opportunities are available. However, agriculture is slower than in other sectors. [2]

Research on the impact of the Covid-19 pandemic on SMEs has also been in Sri Lanka. The study reveals that it requires high economic costs to overcome the effect of the COVID-19 disaster on SMEs in Sri Lanka. The COVID-19 pandemic harms employees and SME operators. The government must continue implementing the policies and assistance to face the Covid-19 pandemic. [3]

There is another study that estimates the impact of the COVID-19 pandemic on small and medium-sized enterprises (SMEs) in seventeen countries. It uses a large representative firm-level database. The study uses a simple model of firm cost-minimization and measures each firm's liquidity shortfall during and after COVID-19. This study framework allows for a rich combination of sectoral and aggregate supply, productivity, and demand shocks. [4]

All businesses, regardless of size, are facing serious challenges, especially those in the aviation, tourism, and hospitality industries, with a real threat of significant declines in revenue, insolvencies, and job losses in specific sectors. Sustaining business operations will be particularly difficult for Small and Medium Enterprises (SMEs). Following travel bans, border closures, and quarantine measures, many workers cannot move to their places of work or carry out their jobs, which has knock-on effects on incomes, particularly for informal and casually employed workers. Consumers in many economies are unable or reluctant to purchase goods and services. Given the current environment of uncertainty and fear, enterprises are likely to delay investments, purchases of goods, and the hiring of workers. Prospects for the economy and the quantity and quality of employment are deteriorating rapidly. [5]

A study in China found how chronic uncertainty caused by crisis events affects the availability of entrepreneurial sources of finance for start-ups and small and medium-sized enterprises (SMEs). The paper shows that these equity investments slumped dramatically in the immediate aftermath of the Covid-19 virus, resulting in a year on year decrease of $60 \%$ in the total volume of investment raised between 2019 and 2020. Overall, enterprise policymakers need to become better attuned at monitoring real-time data sources to mitigate chronic entrepreneurial uncertainty via strategic policy responses.[6]
Another research was conducted in Rwanda, East Africa. It investigated the effects of the Covid-19 pandemic on the socio-economic aspect. The study found that all socioeconomic aspects were severely affected by the Covid-19 pandemic. In particular, the SME business actors also suffered enormous losses. This was caused by the termination of business activities for some time due to local government policies.[7]

Working Party on SMEs and Entrepreneurship (WPSMEE) conducts analysis and provides evidence-based guidance for the design and implementation of SME policies. This note is the sixth update of SME policy responses since early March 2020. Compared to the previous update, the latest forecasts show an increasingly negative impact of the pandemic on global GDP growth. At the same time, whereas surveys since February show that SMEs and entrepreneurs are extremely worried about the impact of COVID-19 on their liquidity position and business survival, the most recent business surveys show some confidence improvements, possibly related to the significant policy efforts to address the SME liquidity gap and the lifting of lockdown measure. [8]

Finally, a study has investigated the impact of social distancing policies on SMEs in Indonesia. It used a quantitative method with a survey design. The result showed that social distancing policies affect SMEs during the COVID19 pandemic. This is indicated by the decreasing income and demand for SME products, and even some have no income (mean values of 2.40) due to the social distancing policies. Besides, the policy's impact is also shown in the increasing cost of raw materials and production costs due to supply chain problems (mean values of 4.79). The policy's impact raises anxiety for SMEs to survive so that business actors change their plans by utilizing information technology (mean values of 4.81). This change is a strategy to survive due to the impact of the applied policies. Although social distancing policies affect SMEs' survival during the pandemic, research findings show that SMEs in Indonesia did not terminate employment. [9]

By combining various thoughts that have been carried out by several previous studies, this study seeks to conduct similar research which is somewhat different from these studies. This study aims to explore the portrait of the impact of the Covid-19 pandemic on micro and small business actors. The research method used is exploration. The study aims are to obtain an initial picture of the micro and small business sector before, during, and after the Covid-19 pandemic. After that, the results of this research can be used by further research. 
III. DESCRIPTIVE ANALYSIS AND DISCUSSION

A. General Category of SMEs Actors in Semarang City

1. Gender Category

\section{GENDER CATEGORY}

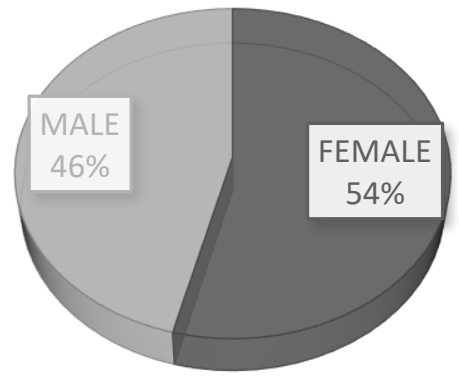

Figure 2: Gender Category of SME actors in Semarang, 2020

Figure 2 shows that women generally dominate SME actors in Semarang. There $54 \%$ of SME actors are female.

2. Age Category

TABLE 1 AGE CATEGORY OF SME ACTORS

\begin{tabular}{|l|c|c|}
\hline Age Category & Amount & Percentage \\
\hline$<20$ years & 32 & $4.6 \%$ \\
\hline $20-30$ years & 215 & $30.7 \%$ \\
\hline $30-40$ years & 160 & $22.9 \%$ \\
\hline $40-50$ years & 175 & $25 \%$ \\
\hline$>50$ years & 119 & $17 \%$ \\
\hline
\end{tabular}

Source: Research in Semarang City, 2020

Table 1 shows that the group of 20-30-year age dominate the SME actors in Semarang. There are $30.7 \%$ of the total respondents in this category. Then there are $25 \%$ of the total respondents in the 40-50 years age group, and there are $22.9 \%$ of the total respondents in the 30-40-year age group.

\section{Type of Business}

TABLE 2 TYPE OF BUSINESS OF SME ACTORS

\begin{tabular}{|l|c|c|}
\hline Type of Business & Amount & Percentage \\
\hline Culinary & 500 & $72.8 \%$ \\
\hline Fashion & 76 & $11.1 \%$ \\
\hline Automotive & 14 & $2.0 \%$ \\
\hline Electronic & 27 & $3.9 \%$ \\
\hline Handicraft & 24 & $3.5 \%$ \\
\hline Agrobusiness & 47 & $6.8 \%$ \\
\hline Internet & 7 & $1.0 \%$ \\
\hline
\end{tabular}

Source: Research in Semarang City, 2020

Table 2 shows the business category of SME actors in Semarang. There are $72.8 \%$ of business actors engaged in the culinary sector. Then, followed by fashion businesses. There are $11.1 \%$ of SME actors in fashion businesses. There are 6.8 $\%$ of SME actors in the agribusiness sector.
4. Business Location

TABLE 3 LOCATION OF BUSINESS OF SME ACTORS

\begin{tabular}{|l|c|c|}
\hline Location & Amount & Percentage \\
\hline Downtown & 98 & $14,0 \%$ \\
\hline East Semarang & 79 & $11.3 \%$ \\
\hline West Semarang & 269 & $38,4 \%$ \\
\hline South Semarang & 73 & $10,4 \%$ \\
\hline North Semarang & 49 & $7,0 \%$ \\
\hline Out of Town & 137 & $19,5 \%$ \\
\hline
\end{tabular}

Source: Research in Semarang City, 2020

Table 3 shows that there is $38.4 \%$ of SMEs choose the location in West Semarang. There is $19.5 \%$ of SMEs choose the location outside Semarang. Then there is $14 \%$ of SMEs do business in the center of Semarang City. Only $7 \%$ of SMEs choose in the North Semarang.

\subsection{Length of Business}

TABLE 4 BUSINESS LENGTH OF SMEs

\begin{tabular}{|l|c|}
\hline Length & Percentage \\
\hline$<1$ year & $15.0 \%$ \\
\hline 1-5 years & $50.0 \%$ \\
\hline 6-10 years & $18.0 \%$ \\
\hline$>10$ years & $17.0 \%$ \\
\hline
\end{tabular}

Source: Research in Semarang City, 2020

Table 4 shows the business length of SMEs in Semarang. There are $50 \%$ of SMEs have been running businesses for between 1 and 5 years. Then there are $35 \%$ of SMEs have been running businesses for more than 5 -years. The rest is 15 $\%$ of SMEs have been running their businesses for less than 1year.

B. Portrait of Micro and Small Business Resources Before the Covid-19 Pandemic

1. Initial Capital

TABLE 5 INITIAL CAPITAL OF SMEs

\begin{tabular}{|l|c|}
\hline Initial Capital (000 IDR) & Percentage \\
\hline$<1,000$ & $43 \%$ \\
\hline $1,000-5,000$ & $43 \%$ \\
\hline $6,000-10,000$ & $9 \%$ \\
\hline \multicolumn{2}{|l}{} \\
Source: Resear in Semarang City 2020
\end{tabular}

Source: Research in Semarang City, 2020

Table 5 shows the initial capital of SMEs in Semarang. This research finds that $43 \%$ of SMEs started the business with an initial capital of fewer than 1 million rupiahs. There are $43 \%$ of SMEs started between 1 and 5 million rupiahs. Only $14 \%$ of SME actors started with an initial capital of more than 6 million rupiahs.

\section{Working Capital}

\section{TABLE 6 WORKING CAPITAL OF SMEs}

\begin{tabular}{|l|c|}
\hline Initial Capital (000 IDR) & Percentage \\
\hline$<1,000$ & $42.9 \%$ \\
\hline $1,000-5,000$ & $43.6 \%$ \\
\hline $6,000-10,000$ & $14.5 \%$ \\
\hline
\end{tabular}

Source: Research in Semarang City, 2020

Table 6 shows the working capital of SMEs in Semarang. There are $43.6 \%$ of SME actors who use the working capital 
between 1 to 5 million rupiahs. There are $42.9 \%$ of SME actors who use the working capital for less than 1 million rupiahs. Only $14.5 \%$ of SME actors who use the working capital for more than 6 million rupiahs.

\section{Number of Worker}

TABLE 7 NUMBER OF WORKER

\begin{tabular}{|l|c|}
\hline Number of Worker & Percentage \\
\hline 1 person & $51 \%$ \\
\hline 2 persons & $22 \%$ \\
\hline 3 persons & $14 \%$ \\
\hline$>3$ persons & $13 \%$ \\
\hline
\end{tabular}

Source: Research in Semarang City, 2020

Table 7 shows the number of the worker in the SME sector. There are $51.1 \%$ of SME actors who are self-employed. Then there are $22.5 \%$ of SME actors run businesses with the help of their husbands or wives. There are only $19.9 \%$ of the SME sector in Semarang who employ other workers.

6. Income Before the Covid-19 Pandemic

TABLE 8 INCOME/DAY BEFORE THE COVID-19 PANDEMIC

\begin{tabular}{|l|c|c|}
\hline $\begin{array}{l}\text { Income Range (IDR } \\
\text { 000) }\end{array}$ & Amount & Percentage \\
\hline$<100$ & 58 & $8.4 \%$ \\
\hline $100-500$ & 405 & $58.9 \%$ \\
\hline $600-1,000$ & 119 & $17.3 \%$ \\
\hline $1,000-2,500$ & 62 & $9.0 \%$ \\
\hline $2,500-5,000$ & 28 & $4.1 \%$ \\
\hline$>5,000$ & 20 & $2.9 \%$ \\
\hline
\end{tabular}

Source: Research in Semarang City, 2020

Table 8 shows the income per day of SME actors before the Covid-19 pandemic. There is $58.9 \%$ of the SME actors earned income between 100,000 and 500,000 rupiahs per day. Then there is $17.3 \%$ of the SME actors earned income between 600,000 and 1,000,000 rupiahs per day. Only $8.4 \%$ of SME actors earned income less than 100,000 rupiahs per day.

7. Income Use Before the Covid-19 Pandemic

TABLE 9 INCOME USE BEFORE THE COVID-19 PANDEMIC

\begin{tabular}{|l|c|c|}
\hline Income Use & Amount & Percentage \\
\hline Basic Consumption & 145 & $21.0 \%$ \\
\hline Consumption \& Saving & 214 & $30.9 \%$ \\
\hline $\begin{array}{l}\text { Consumption \& } \\
\text { Working Capital }\end{array}$ & 112 & $16.2 \%$ \\
\hline $\begin{array}{l}\text { Consumption, Working } \\
\text { Capital \& Saving }\end{array}$ & 225 & $32.5 \%$ \\
\hline
\end{tabular}

Source: Research in Semarang City, 2020

Table 9 shows the income use before the Covid-19 pandemic. There are $48.7 \%$ of SME actors who used income for consumption, working capital, and savings. There are $51.9 \%$ of SME actors who use the income for consumption and saving.
C. Portrait of SMEs Action Against the Covid-19 Pandemic

1. Action against the covid-19 pandemic

TABLE 10 ACTION AGAINST THE COVID-19 PANDEMIC

\begin{tabular}{|l|c|c|}
\hline Action & Amount & Percentage \\
\hline Stop Business & 291 & $42.1 \%$ \\
\hline Never Stop Business & 403 & $58.2 \%$ \\
\hline
\end{tabular}

Source: Research in Semarang City, 2020

Table 10 shows that there are $58.2 \%$ of SME actors did not stop their businesses against covid-19. There are only $42,1 \%$ of SME actors who stopped their businesses against covid-19. The main reason for the SMEs who did not stop their businesses is that they had no choice to survive. All of them had no opportunity to get pandemic assistance from both the government and non-government. Then another reason is that they only sold around where they live.

\section{Reasons for Stopping the Business}

\section{TABLE 11 REASONS FOR STOPPING BUSINESS}

\begin{tabular}{|l|c|c|}
\hline Reasons & Amount & Percentage \\
\hline Government rules & 140 & $48.4 \%$ \\
\hline Own Awareness & 72 & $24.9 \%$ \\
\hline Customer Difficulty & 96 & $33.2 \%$ \\
\hline Capital Difficulty & 15 & $5.2 \%$ \\
\hline Raw Material Difficulty & 16 & $5.5 \%$ \\
\hline
\end{tabular}

Source: Research in Semarang City, 2020

Table 11 shows the reasons for stopping a business during the Covid-19 pandemic. There are $48.4 \%$ reasons for government regulation. Then, there are $24.9 \%$ reasons for their awareness to support the government efforts to prevent the Covid-19 pandemic. But there are $33.2 \%$ reasons for customer difficulties. Only $10.7 \%$ reasons are for working capital and raw materials difficulties.

\section{Duration of Stopping the Business}

TABLE 12 DURATION OF STOPPING THE BUSINESS

\begin{tabular}{|l|c|}
\hline Duration & Percentage \\
\hline 1 month & $44 \%$ \\
\hline $1-3$ months & $39 \%$ \\
\hline $3-5$ months & $9 \%$ \\
\hline $5-7$ months & $8 \%$ \\
\hline
\end{tabular}

Source: Research in Semarang City, 2020

Table 12 shows the duration of stopping the business. There are $44 \%$ of SME actors stopped it for one month. Then, there are $39 \%$ of SME actors stopped it between 1 and 3 months. Only $17 \%$ of SME actors stopped for more than 3-7 months.

\section{Amount of Loss Every Day During Stop Business}

TABLE 13 AMOUNT OF LOSS

\begin{tabular}{|l|c|c|}
\hline Amount of Loss (IDR) & Amount & Percentage \\
\hline$<1$ million & 263 & $65.9 \%$ \\
\hline $1-2.5$ million & 75 & $18.8 \%$ \\
\hline $2.5-5$ million & 31 & $7.8 \%$ \\
\hline$>5$ million & 33 & $8.3 \%$ \\
\hline
\end{tabular}

Source: Research in Semarang City, 2020 
When SME actors stopped their businesses, $65.9 \%$ of them had lost fewer than 1 million rupiahs per day. $18.8 \%$ of SME actors had lost between 1 and 2.5 million rupiahs per day, and $16.1 \%$ had lost more than 2.5 million rupiahs per day.

\section{Number of Recipients of Covid-19 Impact Assistance}

TABLE 14 NUMBER OF RECIPIENTS GRANTS

\begin{tabular}{|l|c|c|}
\hline Grants & Amount & Percentage \\
\hline No Receive & 324 & $79.6 \%$ \\
\hline Receive & 83 & $20.4 \%$ \\
\hline
\end{tabular}

Source: Research in Semarang City, 2020

Table 14 shows the number of recipients of grants. There are only $20.4 \%$ of SME actors receive it to face the impact of the Covid-19 pandemic. There are $79.6 \%$ who did not receive it.

6. Source of Impact Assistance of the Covid-19 Pandemic TABLE 15 SOURCE OF GRANTS

\begin{tabular}{|l|c|c|}
\hline Source & Amount & Percentage \\
\hline Government & 75 & $78.1 \%$ \\
\hline Non-Government & 21 & $21.9 \%$ \\
\hline
\end{tabular}

Source: Research in Semarang City, 2020

Table 15 shows the source of grants. There are $78.1 \%$ of SME actors receive from the government, and $21.9 \%$ from nongovernment.

7. Amount of Covid-19 Impact Assistance

\section{TABLE 16 AMOUNT OF GRANTS}

\begin{tabular}{|l|c|c|}
\hline Amount (000 IDR) & Amount & Percentage \\
\hline$<500$ & 26 & $28.9 \%$ \\
\hline $500-1,000$ & 37 & $41.1 \%$ \\
\hline $1,000-2,500$ & 22 & $24.4 \%$ \\
\hline$>5,000$ & 5 & $5.6 \%$ \\
\hline
\end{tabular}

Source: Research in Semarang City, 2020

Table 16 shows the number of grants. There are $41.1 \%$ of SME actors who received grants between 500,000 and $1,000,000$ rupiahs per month. Only $5.6 \%$ received more than 5 million rupiahs per month.

8. Frequency of Receive Grants Against the Impact of the Covid-19 Pandemic

TABLE 17 FREQUENCY OF RECEIVE GRANTS

\begin{tabular}{|l|c|c|}
\hline Reasons & Amount & Percentage \\
\hline 1 time & 38 & $40.0 \%$ \\
\hline 2 times & 12 & $12.6 \%$ \\
\hline 3 times & 19 & $20.0 \%$ \\
\hline 4 times & 20 & $21.1 \%$ \\
\hline$>4$ times & 6 & $6.3 \%$ \\
\hline
\end{tabular}

Source: Research in Semarang City, 2020

Table 17 shows the frequency of receive grants. There are 40 $\%$ of SME actors received grants only one time. Then $21 \%$ received grants four times, $20 \%$ three times, and $12.6 \%$ two times. Only $6.3 \%$ of SME actors received more than four times.

D. The Portrait of Micro and Small Businesses in the NewNormal Period

1. Amount of Expenditure in New-Normal

TABLE 18 EXPENDITURE/DAY OF SME ACTORS

\begin{tabular}{|l|r|c|}
\hline Expenditure (000) & Amount & Percentage \\
\hline$<500$ & 490 & $72.5 \%$ \\
\hline $500-1,000$ & 132 & $19.5 \%$ \\
\hline
\end{tabular}

\begin{tabular}{|l|c|c|}
\hline $1,000-2,500$ & 28 & $4.1 \%$ \\
\hline $2,500-5,000$ & 23 & $3.4 \%$ \\
\hline$>5,000$ & 7 & $1.0 \%$ \\
\hline
\end{tabular}

Source: Research in Semarang City, 2020

Table 18 shows the expenditure per day in the new normal period. There are $72.5 \%$ of SME actors with expenditures fewer than 500 thousand rupiahs. There are $19.5 \%$ of SME actors with expenditures between 500,000 and 1,000,000 rupiahs. There are $7.5 \%$ of SME actors with expenditures between 1,000,000 and 5,000,000 rupiahs. Only $1 \%$ of SME actors with expenditures of more than 5,000,000 rupiahs.

2. Income per Day in the New-Normal Period

TABLE 19 INCOME/DAY IN THE NEW NORMAL PERIOD

\begin{tabular}{|l|c|c|}
\hline Income (IDR 000) & Amount & Percentage \\
\hline$<500$ & 449 & $62.2 \%$ \\
\hline $600-1,000$ & 173 & $25.1 \%$ \\
\hline $1,000-2,500$ & 38 & $5.5 \%$ \\
\hline $2,500-5,000$ & 26 & $3.8 \%$ \\
\hline$>5,000$ & 10 & $1.5 \%$ \\
\hline
\end{tabular}

Source: Research in Semarang City, 2020

Table 19 shows the income per day of SME actors in the new normal. There is $62.2 \%$ of the SME actors earn an income of fewer than 500,000 rupiahs per day. Then there is $25.1 \%$ of the SME actors earn income between 600,000 and 1,000,000 rupiahs per day. Only $1.5 \%$ of SME actors earn income more than 5,000,000 rupiahs per day. It means that most of the SME actors have a declining income per day.

\section{Expenditure per Day in New Normal Period}

TABLE 20 INCOME USAGE/DAY IN NEW NORMAL PERIOD

\begin{tabular}{|l|c|c|}
\hline Income Use & Amount & Percentage \\
\hline Basic Consumption & 28 & $4.0 \%$ \\
\hline Consumption \& Saving & 148 & $21.1 \%$ \\
\hline $\begin{array}{l}\text { Consumption \& } \\
\text { Working Capital }\end{array}$ & 188 & $26.9 \%$ \\
\hline $\begin{array}{l}\text { Consumption, Working } \\
\text { Capital \& Saving }\end{array}$ & 340 & $48.7 \%$ \\
\hline
\end{tabular}

Source: Research in Semarang City, 2020

Table 20 shows the income usage per day of SME actors in the new normal. There are $48.7 \%$ used for consumption, working capital, and savings. There are $26.9 \%$ of SME actors who used income per day for consumption and working capital, $21.1 \%$ of SME actors used it for consumption and saving. Only $4.0 \%$ of SME actors used it for consumption.

\section{CONCLUSION}

1. SME actors in Semarang are generally dominated by women. They are in the age range of 20 to 30 years.

2. They prefer to choose the location in the western of Semarang. That area is experiencing the development of economic and business activities.

3. These micro and small entrepreneurs prefer to be engaged in culinary and fashion businesses.

4. Their business is very much supported by business digitization by utilizing on-line methods. 
5. In the Covid-19 pandemic period, most of the respondents in this study had a stance to keep running their business.

6. The Covid-19 pandemic had an impact on SMEs in Semarang City.

7. There is a change in business patterns between the period before and after the Covid-19 pandemic.

8. Most of the respondents in this study showed the characteristics of being a true entrepreneur. In general, they are not giving up on facing the Covid-19 pandemic. For them, this condition can provide new opportunities for their business.

\section{SUGGESTION}

1. The City Government should be able to carry out continuous evaluations of the covid-19 impact assistance program.

2. Future research can use this research to develop a new model of SME management science.

\section{REFERENCES}

[1] J. Shamsuddin, M. N. Sarkawi, A. R. Jaafar, and N. F. Abd Rahim, "Malaysian SMEs performance and the government business support service: The moderating effects of absorptive capacity," Int. J. Supply Chain Manag., 2017.

[2] Y. Zhang, X. Diao, K. Z. Chen, S. Robinson, and S. Fan, "Impact of COVID-19 on China's macroeconomy and agri-food system - an economy-wide multiplier model analysis," China Agric. Econ. Rev., 2020, doi: 10.1108/CAER-04-2020-0063.

[3] J. Robinson and N. Kengatharan, "Exploring the effect of Covid-19 on Small and Medium Enterprises: Early Evidence from Sri Lanka,' Journal of Applied Economics and Business Research JAEBR. 2020.

[4] S. Kalemli-Ozcan, P.-O. Gourinchas, V. Penciakova, and N. Sander, "COVID-19 and SME Failures," IMF Work. Pap., 2020, doi 10.5089/9781513557748.001.

[5] ILO, "COVID-19 and the world of work: Impact and policy responses," Int. Labour Organ., 2020.

[6] R. Brown and A. Rocha, "Entrepreneurial uncertainty during the Covid-19 crisis: Mapping the temporal dynamics of entrepreneurial finance," J. Bus. Ventur. Insights, 2020, doi: 10.1016/j.jbvi.2020.e00174.

[7] A. Bizoza and S. Sibomana, "Indicative Socio-Economic Impacts of the Novel Coronavirus (Covid-19) Outbreak in Eastern Africa: Case of Rwanda,” SSRN Electron. J., 2020, doi: 10.2139/ssrn.3586622.

[8] OECD, "Coronavirus ( COVID-19 ): SME Policy Responses," OECD Policy Responses to Coronavirus (COVID-19). 2020.

[9] M. Lutfi, P. C. D. Buntuang, Y. Kornelius, Erdiyansyah, and B. Hasanuddin, "The impact of social distancing policy on small and medium-sized enterprises (SMEs) in Indonesia," Probl. Perspect. Manag., 2020, doi: 10.21511/ppm.18(3).2020.40. 